\title{
Utilization of integrated health kiosks: A systematic review
}

\author{
Mozhgan Letafat-nejad $^{1}$, Parvin Ebrahimi*1 (D), Mohammadreza Maleki ${ }^{1}$, Aidin Aryankhesal ${ }^{1}$
}

Received: 25 Dec 2019

Published: 5 Sep 2020

\begin{abstract}
Background: In some countries, integrated health kiosks are used to provide some services and information. However; it is still not officially included in many countries' health systems. The purpose of this study was to gather and summarize different aspects of using health kiosks in countries.

Methods: Five English databases, including Web of Science, Cochrane Library, PubMed / Medline, Embase and Scopus, were explored from 2001 to 2018, using words related to three concepts: health, design and development, and kiosk. Different dimensions of health kiosks utilization in the world were identified and analyzed thematically.

Results: Out of 918 search results, 37 articles were included in the study and analyzed. Most of them were conducted in the United States and addressed the development, implementation, design, or feasibility of utilizing integrated health kiosks. The different aspects of kiosk utilization were categorized into 6 dimensions: services provided, deployment location, user characteristics and variables of accepting kiosks, notable design and construction points, their benefits and effectiveness, and finally, the challenges of using kiosks.

Conclusion: This study found that health kiosks are promising, cost-effective and multifunctional tools; if included in the formal health system of countries, they may improve health indicators in countries. However, before deploying, their challenges and concerns need to be investigated and addressed.
\end{abstract}

Keywords: Health kiosk, Utilization, Implementation, Systematic review

Conflicts of Interest: None declared

Funding: Iran University of Medical Sciences

*This work has been published under CC BY-NC-SA 1.0 license.

Copyright $₫$ Iran University of Medical Sciences

Cite this article as: Letafat-nejad M, Ebrahimi P, Maleki M, Aryankhesal A. Utilization of integrated health kiosks: A systematic review. Med $J$ Islam Repub Iran. 2020 (5 Sep);34:114. https://doi.org/10.47176/mjiri.34.114

\section{Introduction}

The health kiosks play an important role in health care industry (1). They are touch screen computer-based terminals which are usually standing in public or specialized health areas (1-4). Unlike old versions of kiosks, opportunistic, the integrated kiosks are not just limited to providing information and consulting services but turning to hygienic, diagnostic and sometimes medical services (4-6). They make the provision of services and supply of medicines cheaper, faster, and easier, tailored to the client's time and desire (2).

Its benefits, the increased efficiency and cost-saving (7), increased accessibility, saving staff and patients' time, and

\footnotetext{
Corresponding author: Dr Parvin Ebrahimi, ebrahimi.p@iums.ac.ir
}

1. Department of Health Services Management, School of Health Management and Information Sciences, Iran University of Medical Sciences, Tehran, Iran reduced health-care weaknesses (8), improved patient safety (9), improved self-care and management of chronic diseases (10), reduced medication errors caused by the discrepancy between drug prescriptions (11), and identification and screening of new chronic diseases (12) have been mentioned in various studies. They can also provide some health services in disasters.

On the other hand, there are some concerns about the use of health kiosks too. Device and data security and quality, privacy, service tariff, advertising protocol, and most importantly- the inability to convey the emotions, hope, and convenience to patients need to be thought out;

$\uparrow$ What is "already known" in this topic:

Health kiosks are widely used in some countries and can significantly improve the health indicators.

$\rightarrow$ What this article adds:

This study provided a comprehensive view of how health kiosks are used in the world and its results can be used in decision making about integrating kiosks into the formal health system of countries. 
and the right solutions should be found (13).

Yet, this tool has not been included in some countries' formal health systems. The policymakers and investors require a comprehensive view of experiences in different countries to be justified to develop and deploy kiosks. The managers also need to know how to deliver services through kiosks, what will be the outcomes, what are benefits and challenges, etc.

The diversity of health kiosks and provided services, on the other hand, it has led to inconsistency in the findings of studies. For example, Chan et al. found that these kiosks are welcomed more at shopping centers, docks, walkin centers, and "Kwik Save" supermarkets (14), while Jones et al. showed that they are more welcomed at specialized medical places (1); Similarly, Eva et al. showed that the majority of kiosk users are women aged 30-50 years old, with postgraduate education and above, and with medium- upper income (75- 150 \$) (15), while Chan et al. believed that the gender, age, education level, race, neighborhood, and length of stay of users in the clinic waiting room did not significantly affect the effectiveness of kiosks (14).

Despite limited systematic studies in this area, the current highly changing environment, especially in the health technology industry, necessitates the periodical updating of information (16). Therefore, this study aimed to investigate all studies that had been conducted from 2001 to 2018 which revealed how the health kiosks are being used over the countries in order to provide a comprehensive vision and sufficient evidence about installing kiosks for health decision-makers in other countries.

\section{Methods}

This study was conducted according to the systematic review and meta-analytic (PRISMA) reporting guide (17). Studies with the following criteria were included in the review: 1- Related to integrated kiosks. 2- Describing how to use the kiosks. 3- Available in English. 4- Published between 2001 and September 2018. The exclusion criteria were: 1- Focus solely on technical, specialized, and software dimensions of developing kiosks. 2- Non-scientific articles such as newsletters or reports and 3- Poor quality of the study.

To identify eligible studies, we used three search strategies; searching electronic databases, reference mining, and searching web databases.

1. Searching electronic databases: Five databases, including Web of Science, Cochrane Library, PubMed / Medline, Embase and Scopus, were searched from 2001 until the end of September 2018. Three word groups including health, design and development, and kiosk were searched. Since this study investigated the integrated health kiosks, the studies associated with opportunistic kiosks (first generation kiosks) were ignored. An example of searching on the scopus database is provided in the Appendix.

2. Reference mining: After finding related articles, their references were reviewed, and in the case of meeting inclusion criteria, they were manually searched on Google, Google Scholar, or the journal site.
3. Searching websites: To find some gray literature, Google, Google Scholar, and some specialized health kiosk websites (https://kiosk.com and https://www.kioskmarket place.com) were searched.

The searches were independently conducted by two researchers and verified by a third person. Finally, the duplicate articles were removed using Endnote X9 software.

Figure 1 illustrates the process of selecting articles in PRISMA format. Out of 918 search results, and after removing the duplicates, 429 articles were investigated. Two researchers independently skimmed through the titles and abstracts of the papers and matched them with inclusion and exclusion criteria. The results of two researchers were compared at each stage and consulted with a third party in the case of disagreements. We read papers in full text when they seemed to meet the eligibility criteria.

To perform a methodological quality assessment of the studies, a researcher-made checklist consisting of 10 questions was used. Each researcher independently reviewed the studies. The disagreements were resolved through discussion and arbitration by the third person.

Each line of selected articles was studied completely by two researchers independently to extract the data. The relevant data along with the name of authors, year of completion, country, the purpose of study, location of kiosk deployment, and type of provided services were recorded in a researcher-made form (Table 1).

The selected studies were categorized by purpose and listed in Table 1. The data collection form was designed based on identified dimensions in studies (Table 1). Then, the collected data was classified and thematically analyzed.

\section{Results}

Finally, 37 articles were included in the study (Fig. 1).

According to Table 1, the purpose of 10 studies was to evaluate users' opinions about acceptability, usability, satisfaction, and adaptation of kiosks; 19 studies addressed the development, implementation, design, or feasibility of utilizing integrated health kiosks; 6 studies evaluated their effectiveness; 3 studies examined them in terms of cost; 2 studies evaluated the kiosks; and 4 studies assessed the role of kiosks in the health system (Some studies investigate more than one objective).

Figure 2 also shows the explanation of identified dimensions at studies. Most studies referred to the type of service provided in kiosks. The issue "notable design and construction points" was less considered in studies.

The literature review results are provided in six categories: offered services in kiosks, their benefits and effectiveness, deployment locations, user characteristics and variables of accepting kiosks, requirements needed to be considered in designing and constructing the kiosks, and challenges and disadvantages of using kiosks.

\section{Provided service}

The functions of integrated health kiosks were classified into prevention, treatment and diagnosis, counseling and training, patient profile and history, and others (Table 2). Some functions of kiosks overlap in classification. 


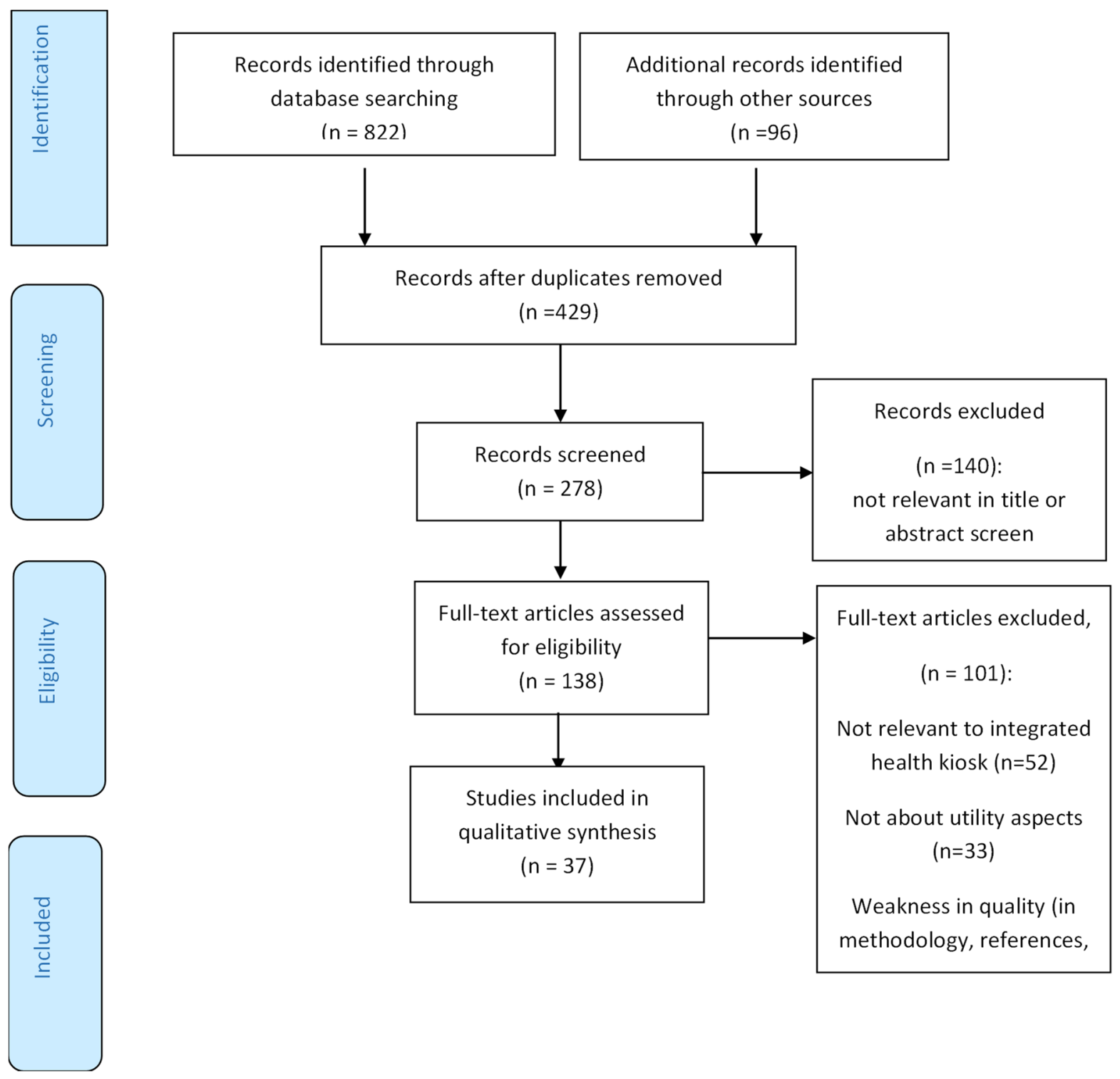

Fig. 1. Literature search flow diagram

\section{Benefits and effectiveness of kiosks}

Studies investigated the effectiveness of kiosks were 13; two articles confirmed the effectiveness of kiosks in managing asymptomatic urinary tract infections in women $(15,18)$. Also, the decreased mortality due to reduction of superstitions in health area (19), improvement of health status among elderly people (20), management of drug use (11), accurate results of kiosks in controlling vital symptoms (11) such as hypertension $(10,21)$, effective nutritional management (14), increased HIV screening (22), increased mental illness screening (23), and saving time for nurses without decreasing the quality and accuracy of services (24) were confirmed in studies. The utilization of kiosks in the emergency department also reduced the number of patients who departed before contacting a triage provider (25).

Other benefits listed in reviewed studies are as follows:

Reduced patient waiting time (18), reduced superstitions and subsequently reduced neonatal mortality (19), easier blood pressure control, increased patient participation in self-care, and saving staff time $(21,26)$, reduced need for physicians and health care providers, especially primary health care (10), increased health and prevention literacy (14), easy training of staff at the workplace, more screening of people at risk, self-care training according to individual characteristics, staff biometric tracking, integration between individual biometric data and online health records, increased patient satisfaction due to reduced waiting time, increased service delivery, paying more attention to patient privacy, increased patient power, higher accuracy of demographic information in patient's record, better management of chronic diseases, better access to health care services (6) and saving users time (27).

\section{Locations}

The deployment locations of kiosks are listed in Table 3. 


\begin{tabular}{|c|c|c|c|c|c|c|}
\hline & Author (Year) & Country & Issue (Purpose) & Categorized aims & Setting & $\begin{array}{l}\text { Service provided by the } \\
\text { kiosk }\end{array}$ \\
\hline 1 & $\begin{array}{l}\text { Olufunmilola, et al. } \\
\qquad \text { (2018) }\end{array}$ & USA & $\begin{array}{l}\text { To explore the acceptability, usability, usefulness, and } \\
\text { overall satisfaction of health kiosks (18) }\end{array}$ & $\begin{array}{l}\text { - Acceptability, usability, satisfaction, } \\
\text { adaptation }\end{array}$ & $\begin{array}{c}\text { African American majority } \\
\text { community settings such as } \\
\text { churches and community } \\
\text { centers }\end{array}$ & Health \\
\hline 2 & Hsieh, et al. (2014) & USA & $\begin{array}{l}\text { To evaluate the feasibility and the patient acceptability of } \\
\text { integrating a kiosk into routine practice for offering (19) }\end{array}$ & $\begin{array}{l}\text { - Acceptability, usability, satisfaction, } \\
\text { adaptation } \\
\text { - Development, implement, design, } \\
\text { feasibility }\end{array}$ & $\mathrm{ED}$ & HIV testing \\
\hline 3 & Eva, et al. (2006) & USA & $\begin{array}{l}\text { To validate and implement a computer module for the } \\
\text { health kiosk (16) }\end{array}$ & $\begin{array}{l}\text { - Development, implement, design, } \\
\text { feasibility }\end{array}$ & Urgent care clinic & $\begin{array}{l}\text { Management of uncompli- } \\
\text { cated urinary tract infections } \\
\text { (UTI) }\end{array}$ \\
\hline 4 & $\begin{array}{l}\text { Maunder, et al. } \\
\text { (2018) }\end{array}$ & Canada & $\begin{array}{l}\text { To develop an internet self-assessment resource that fills } \\
\text { the identified gap and collects data to generate and test } \\
\text { hypotheses about health, to test its feasibility, and to de- } \\
\text { scribe the characteristics of its users (20) }\end{array}$ & $\begin{array}{l}\text { - Acceptability, usability, satisfaction, } \\
\text { adaptation } \\
\text { - Development, implement, design, } \\
\text { feasibility }\end{array}$ & $\begin{array}{l}\text { Not reported; Entire care } \\
\text { clinic }\end{array}$ & $\begin{array}{l}\text { Overall mental and physical } \\
\text { health }\end{array}$ \\
\hline 5 & Sara L, et al. (2012) & USA & To check the effectiveness of kiosks (21) & - Evaluate the effectiveness & $\begin{array}{l}\text { Hospital urgent care clin- } \\
\text { ic/EDs }\end{array}$ & $\begin{array}{l}\text { diagnose and expedite } \\
\text { treatment of urinary tract } \\
\text { infections (UTI) }\end{array}$ \\
\hline 6 & $\begin{array}{l}\text { Sherilyn KD, et al. } \\
\qquad(2012)\end{array}$ & Canada & $\begin{array}{l}\text { To develop an economic model based on the use of phar- } \\
\text { macy-based blood pressure kiosks for case finding of remu- } \\
\text { nerable medication therapy management (MTM) opportuni- } \\
\text { ties (14) }\end{array}$ & $\begin{array}{l}\text { - Development, implement, design, } \\
\text { feasibility } \\
\text { - Evaluate the effectiveness }\end{array}$ & Pharmacies & $\begin{array}{l}\text { Pharmacy-based blood } \\
\text { pressure }\end{array}$ \\
\hline 7 & $\begin{array}{l}\text { Venkatesh, et al. } \\
\qquad(2016)\end{array}$ & India & $\begin{array}{l}\text { To examine how the use of one ICT intervention specifical- } \\
\text { ly, eHealth kiosks disseminating authenticated and accessi- } \\
\text { ble medical information, can alleviate the problem of high } \\
\text { infant mortality (22) }\end{array}$ & - Evaluate the effectiveness & Rural India/villages & $\begin{array}{l}\text { Infant care awareness and to } \\
\text { modify healthcare behav- } \\
\text { iors. }\end{array}$ \\
\hline 8 & $\begin{array}{l}\text { Zwicker M, et al. } \\
\text { (2012) }\end{array}$ & Germany & $\begin{array}{l}\text { To identify possibilities pertaining to how health kiosks can } \\
\text { be adapted to ensure that all people can use these, effective- } \\
\text { ly and efficiently (23) }\end{array}$ & - Effect on health system overall & - & - \\
\hline 9 & $\begin{array}{l}\text { MacDonald, et al. } \\
\text { (2014) }\end{array}$ & $\begin{array}{c}\text { New } \\
\text { Zealand }\end{array}$ & $\begin{array}{l}\text { To introduce a healthcare robot system and examine it in a } \\
\text { real environment (24) }\end{array}$ & $\begin{array}{l}\text { - Development, implement, design, } \\
\text { feasibility }\end{array}$ & Private and public spaces & $\begin{array}{l}\text { managing older people } \\
\text { health conditions }\end{array}$ \\
\hline 10 & $\begin{array}{l}\text { Lesselroth BJ, et al. } \\
\qquad(2009)\end{array}$ & USA & $\begin{array}{l}\text { To describe the design and implementation of Automated } \\
\text { Patient History Intake Device (APHID), an ambulatory } \\
\text { check-in kiosks (13) }\end{array}$ & $\begin{array}{l}\text { - Development, implement, design, } \\
\text { feasibility }\end{array}$ & $\begin{array}{l}\text { Pharmacies in ambulatory } \\
\text { clinics serving a veteran } \\
\text { population }\end{array}$ & $\begin{array}{l}\text { Allow patients to review } \\
\text { their demographic and med- } \\
\text { ical names, dosage, frequen- } \\
\text { cy, and pictures of their } \\
\text { medications before their } \\
\text { appointment. }\end{array}$ \\
\hline
\end{tabular}




\begin{tabular}{|c|c|c|c|c|c|c|}
\hline & Author (Year) & Country & Issue (Purpose) & Categorized aims & Setting & $\begin{array}{l}\text { Service provided by the } \\
\text { kiosk }\end{array}$ \\
\hline 11 & Lyu Y, et al. (2015) & Chine & $\begin{array}{l}\text { To design and optimization of a prototype healthcare kiosk } \\
\text { to collect vital signs measures (25) }\end{array}$ & $\begin{array}{l}\text { - Development, implement, design, fea- } \\
\text { sibility }\end{array}$ & Public spaces & Vital signs measures \\
\hline 12 & $\begin{array}{l}\text { Courtney, K. et al. } \\
\text { (2013) }\end{array}$ & USA & $\begin{array}{l}\text { To design and development of a multi-user health kiosk } \\
\text { intended for independent use (26) }\end{array}$ & $\begin{array}{l}\text { - Development, implement, design, fea- } \\
\text { sibility }\end{array}$ & Underserved populations & - \\
\hline 13 & $\begin{array}{l}\text { Grace Ng, et al. } \\
\qquad(2016)\end{array}$ & Singapore & $\begin{array}{l}\text { To describe the development and usage of an automated } \\
\text { healthcare kiosk for the management (12) }\end{array}$ & $\begin{array}{l}\text { - Acceptability, usability, satisfaction, } \\
\text { adaptation } \\
\text { - Development, implement, design, fea- } \\
\text { sibility }\end{array}$ & Primary care setting. & $\begin{array}{l}\text { Patients with stable } \\
\text { chronic disease }\end{array}$ \\
\hline 14 & $\begin{array}{l}\text { Hopfer S, et al. } \\
\qquad(2017)\end{array}$ & Tanzania & $\begin{array}{l}\text { describing the adaptation process of re-designing \& imple- } \\
\text { menting an NCI research tested intervention program } \\
\text { (RTIP) (27) }\end{array}$ & $\begin{array}{l}\text { - Development, implement, design, fea- } \\
\text { sibility }\end{array}$ & Community clinic setting & HPV testing \\
\hline 15 & Green B, et al. (2016) & USA & $\begin{array}{l}\text { To evaluate BP kiosk acceptability, usability, and impact on } \\
\text { the workflow of patient BP self-measurement (28) }\end{array}$ & $\begin{array}{l}\text { - Acceptability, usability, satisfaction, } \\
\text { adaptation } \\
\text { - Evaluate the effectiveness }\end{array}$ & Primary care clinics. & $\begin{array}{l}\text { BP and vital signs } \\
\text { measures }\end{array}$ \\
\hline 16 & $\begin{array}{l}\text { Grace Ng, et al. } \\
\quad(2018)\end{array}$ & Singapore & $\begin{array}{l}\text { To evaluate the health outcomes of patients with chronic } \\
\text { disease who are on kiosk management compared with pa- } \\
\text { tients who are on routine management by nurse clinicians } \\
\text { (29) }\end{array}$ & - Evaluate the effectiveness & Primary care setting. & $\begin{array}{l}\text { Managing patients with } \\
\text { chronic disease }\end{array}$ \\
\hline 17 & $\begin{array}{l}\text { Chung CF, et al. } \\
\text { (2016) }\end{array}$ & USA & $\begin{array}{l}\text { To evaluate BP kiosk acceptability and usability, as well as } \\
\text { its effects on the workflow ( } 30)\end{array}$ & $\begin{array}{c}\text { - Acceptability, usability, satisfaction, } \\
\text { adaptation } \\
\text { - Evaluate the effectiveness }\end{array}$ & Primary care clinic. & BP measures \\
\hline 18 & Jones JT, et al. (2008) & USA & $\begin{array}{l}\text { Investigating the Effect of implementation of Health kiosks } \\
\text { in the ED on the LWBS Index (Emergency Departures of } \\
\text { Patients Without Visits of Physicians) (31) }\end{array}$ & - Evaluate the effectiveness & ED & - \\
\hline 19 & Tse J, et al. (2014) & USA & $\begin{array}{l}\text { To identify behavioral and organizational barriers and facil- } \\
\text { itators related to the implementation of a clinic-based pedi- } \\
\text { atric injury prevention program (32) }\end{array}$ & $\begin{array}{l}\text { - Development, implement, design, fea- } \\
\text { sibility }\end{array}$ & Pediatric clinics & $\begin{array}{l}\text { Pediatric injury preven- } \\
\text { tion services }\end{array}$ \\
\hline 20 & $\begin{array}{l}\text { Chan YF, et al. } \\
\text { (2014) }\end{array}$ & USA & $\begin{array}{l}\text { To review current literature for the utilization of kiosks for } \\
\text { the delivery of patient education (15) }\end{array}$ & - & $\begin{array}{l}\text { MEDLINE databases and } \\
\text { Google Scholar for the } \\
\text { years 1996-2014 }\end{array}$ & - \\
\hline 21 & $\begin{array}{l}\text { Hsieh YH, et al. } \\
\qquad(2016)\end{array}$ & USA & $\begin{array}{l}\text { To investigated incremental cost-effectiveness ratio (CER) } \\
\text { per new HIV diagnosis for a kiosk-based approach, versus a } \\
\text { testing staff-based approach ( } 33 \text { ) }\end{array}$ & - Evaluate the effectiveness & ED rewards & HIV screening \\
\hline 22 & $\begin{array}{l}\text { Courtney KL, et al. } \\
\text { (2010) }\end{array}$ & USA & $\begin{array}{l}\text { To examine the acceptability and perceived value of com- } \\
\text { munity-based telehealth kiosks (34) }\end{array}$ & $\begin{array}{l}\text { - Acceptability, usability, satisfaction, } \\
\text { adaptation }\end{array}$ & Public settings & $\begin{array}{l}\text { Health self-management } \\
\text { services of community- } \\
\text { dwelling older adults }\end{array}$ \\
\hline 23 & Takyi H, et al. (2017) & USA & $\begin{array}{l}\text { To provide a guide to create and maintain a multi-user } \\
\text { health kiosks (35) }\end{array}$ & - Evaluation of health kiosk & Public settings & $\begin{array}{l}\text { Services using by older } \\
\text { adults }\end{array}$ \\
\hline
\end{tabular}




\begin{tabular}{|c|c|c|c|c|c|c|}
\hline & Author (Year) & Country & Issue (Purpose) & Categorized aims & Setting & $\begin{array}{c}\text { Service provided by the } \\
\text { kiosk }\end{array}$ \\
\hline 24 & $\begin{array}{l}\text { Mello MM, et al. } \\
\text { (2014) }\end{array}$ & Brazil & $\begin{array}{l}\text { testing ultraviolet protection on sunglasses by self-service } \\
\text { kiosks (36) }\end{array}$ & - Evaluate the effectiveness & Public settings & Public \\
\hline 25 & $\begin{array}{l}\text { Lesselroth B, et al. } \\
\text { (2011) }\end{array}$ & USA & $\begin{array}{l}\text { To describe the implementation of a self-service patient } \\
\text { kiosk intended to check-in patients for a clinic appointment } \\
\text { and collect a medication adherence history, which is then } \\
\text { available through the electronic health record ( } 37 \text { ) }\end{array}$ & $\begin{array}{l}\text { - Development, implement, design, } \\
\text { feasibility }\end{array}$ & Clinics & $\begin{array}{l}\text { Collect a medication adher- } \\
\text { ence history, which is then } \\
\text { available through the elec- } \\
\text { tronic health record }\end{array}$ \\
\hline 26 & $\begin{array}{l}\text { Mandato, et al. } \\
\quad(2010)\end{array}$ & USA & $\begin{array}{l}\text { To examine the best practices for a successful rollout of } \\
\text { check-in kiosks from the perspectives of frontline service } \\
\text { employees (FLSEs), the benefits and positive experiences } \\
\text { of the kiosks, and those factors that helped to motivate the } \\
\text { FLSEs to perform their role in promoting the use of the } \\
\text { kiosks ( } 38 \text { ) }\end{array}$ & $\begin{array}{l}\text { - Acceptability, usability, satisfac- } \\
\text { tion, adaptation }\end{array}$ & Outpatient medical setting & - \\
\hline 27 & $\begin{array}{l}\text { Porter SC, et al. } \\
\qquad(2004)\end{array}$ & USA & To development and evaluation of an asthma kiosk (39) & $\begin{array}{l}\text { - Development, implement, design, } \\
\text { feasibility } \\
\text { - Evaluation of health kiosk }\end{array}$ & ED & $\begin{array}{l}\text { Collect the relevant history } \\
\text { of pediatric asthmatic pa- } \\
\text { tients }\end{array}$ \\
\hline 28 & $\begin{array}{l}\text { Connell CM, et al. } \\
\text { (2003) }\end{array}$ & USA & $\begin{array}{l}\text { to describe the development and implementation of an } \\
\text { Alzheimer's disease (AD) module for the Michigan Interac- } \\
\text { tive Health Kiosk Project (40) }\end{array}$ & $\begin{array}{l}\text { - Development, implement, design, } \\
\text { feasibility }\end{array}$ & Public places & $\begin{array}{l}\text { Interactive Health Kiosk } \\
\text { which provides services for } \\
\text { Alzheimer's patients. }\end{array}$ \\
\hline 29 & $\begin{array}{l}\text { Ray Jones, et al. } \\
\text { (2009) }\end{array}$ & UK & To clarify The role of Health Kiosks in 2009 (1) & - Effect on health system overall & Internet & $\begin{array}{l}\text { Integrated and opportunistic } \\
\text { kiosks }\end{array}$ \\
\hline 30 & $\begin{array}{l}\text { Shahmoradi L, et al. } \\
\text { (2015) }\end{array}$ & Iran & To clarify The role of Health Kiosks in Iran (5) & - Effect on health system overall & Internet & $\begin{array}{l}\text { Integrated and opportunistic } \\
\text { kiosks }\end{array}$ \\
\hline 31 & $\begin{array}{l}\text { Maunder R G, et al. } \\
\qquad(2018)\end{array}$ & Canada & $\begin{array}{l}\text { To Develop an Internet resource that allows self-assessing } \\
\text { mental health problems and test the feasibility of the device } \\
\text { (41) }\end{array}$ & $\begin{array}{l}\text { - Development, implement, design, } \\
\text { feasibility }\end{array}$ & Primary care clinic. & Mental health services \\
\hline 32 & Sinha M, et al. (2014) & USA & $\begin{array}{l}\text { To determine if parents of pediatric ED patients who used } \\
\text { the audio-assisted bilingual (English/Spanish) self-triage } \\
\text { kiosk, were able to enter their child's medical history data } \\
\text { using a touch screen panel ( } 42 \text { ) }\end{array}$ & $\begin{array}{l}\text { - Acceptability, usability, satisfac- } \\
\text { tion, adaptation }\end{array}$ & Pediatric emergency department & $\begin{array}{l}\text { Enter the child's medical } \\
\text { history data by parents }\end{array}$ \\
\hline 33 & $\begin{array}{l}\text { Courtney KL, et al. } \\
\text { (2015) }\end{array}$ & USA & $\begin{array}{l}\text { To learn how community-dwelling older adults would } \\
\text { interact with our prototype multi-user telehealth kiosk and } \\
\text { their views about its usability ( } 43 \text { ) }\end{array}$ & $\begin{array}{l}\text { - Acceptability, usability, satisfac- } \\
\text { tion, adaptation }\end{array}$ & Public places & Older adults health services \\
\hline 34 & $\begin{array}{l}\text { Glenda Wrenn, et al. } \\
\qquad(2015)\end{array}$ & USA & To determine the feasibility of using a kiosk (44) & $\begin{array}{l}\text { - Development, implement, design, } \\
\text { feasibility }\end{array}$ & Primary care clinic & $\begin{array}{l}\text { Screen for multiple mental } \\
\text { health disorders. }\end{array}$ \\
\hline 35 & $\begin{array}{l}\text { Lesselroth B, et al. } \\
\qquad(2009)\end{array}$ & USA & $\begin{array}{l}\text { To develop a standardized medication reconciliation pro- } \\
\text { cess }(45)\end{array}$ & $\begin{array}{l}\text { - Development, implement, design, } \\
\text { feasibility }\end{array}$ & $\begin{array}{c}\text { Chemotherapy administration } \\
\text { unit }\end{array}$ & $\begin{array}{l}\text { standardized medication } \\
\text { reconciliation process }\end{array}$ \\
\hline 36 & $\begin{array}{l}\text { Cohen AN, et al. } \\
\text { (2013) }\end{array}$ & USA & $\begin{array}{l}\text { To develop a patient-facing kiosk to support quality im- } \\
\text { provement at mental health clinics (46) }\end{array}$ & $\begin{array}{l}\text { - Development, implement, design, } \\
\text { feasibility }\end{array}$ & Mental health clinics & Collect routine medical data \\
\hline 37 & $\begin{array}{l}\text { Afzali M, et al. } \\
\qquad(2017)\end{array}$ & Iran & $\begin{array}{l}\text { To determine the data requirements and basis for designing } \\
\text { health kiosks as a new technology to maintain the health of } \\
\text { society (47) }\end{array}$ & $\begin{array}{l}\text { - Development, implement, design, } \\
\text { feasibility }\end{array}$ & Internet/Hospital & Health information kiosk \\
\hline
\end{tabular}




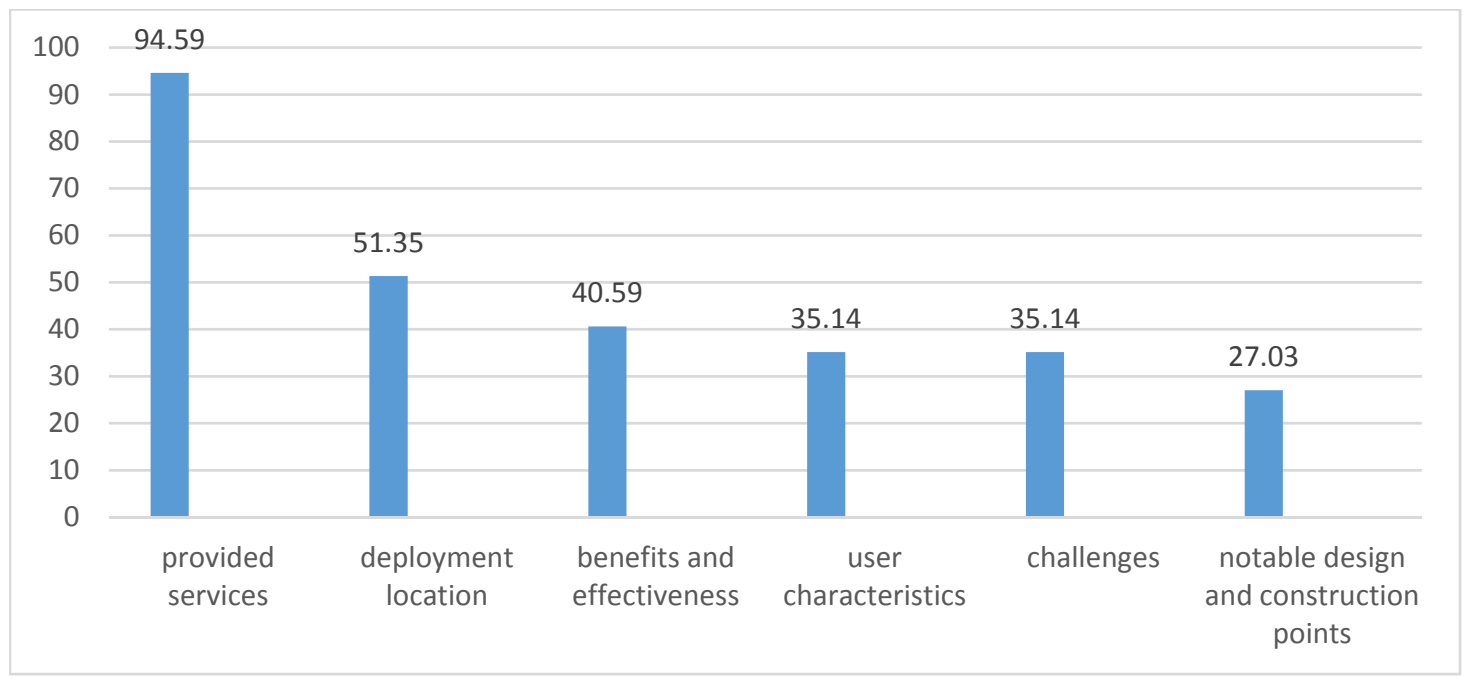

Fig. 2. Studies explaining each utility dimensions

Table 2. Types of services offered in integrated kiosks

Item number Categorized services

Prevention services

2 Diagnostic and therapeutic services

Management and treatment of asthma in children $(1,27)$, Alzheimer $(28)$, Back pain $(1,19,21)$, chronic diseases with controlling vital symptoms such as hypertension $(14,23,24,29-31)$ as well as weight and height (12), automatic measurement of body mass index (BMI), height, weight, body fat percentage, etc.(5), HIV testing $(32,33)$, asymptomatic urinary tract infections in women $(16,34)$, mental health and diagnosis and management of mental illness $(1,35-$ $37)$, psychological problems in patients with cancer $(2,19)$, presentation of probable diagnoses (1) and management of weight in patients with schizophrenia (38).

$3 \quad$ Consulting and training services

Consultation with diabetic patients (2), Preoperative anesthesia counseling (1), computerized interviewing with the patient (2), providing body-based nutrition and motor information (5), providing health education on stress, diabetes, hypertension, healthy diet and exercise, cancer prevention such as skin and breas cancer, fever management, dental care, sleep status, nutrition, car seats, and asthma $(15,21)$.

4 Characteristics registration and Patients' medical history and medication error management $(13,19,39,40)$ such as improved use of antibiotics for respiratory infections $(21)$, patient admispatient history sion and discharge records (24), emergency department admission (41), recording patients' medical history $(1,19,42)$.

Others

Evaluation of sunglasses protection from UV

(43), receiving physician visits $(19,24)$, validation of original and supplementary insurance of patients, and Evaluation of sunglasses protection
assessing patient satisfaction $(24)$ 


\begin{tabular}{|c|c|}
\hline Type of locations & Examples \\
\hline Specialized centers & $\begin{array}{l}\text { Hospitals }(6,28,29) \\
\text { Health clinics }(31) \text {, primary care clinics }(6,10,11,21,23,32,33) \\
\text { Specialized clinics }(26) \\
\text { Emergency departments }(18,25,34,35) \\
\text { Pharmacies }(6,12,28,3)\end{array}$ \\
\hline Public centers & $\begin{array}{l}\text { Villages }(19,30) \\
\text { Groceries or supermarkets }(6,28,29,31) \\
\text { Schools }(29,31) \\
\text { Churches }(29) \\
\text { Shopping centers }(6,29) \\
\text { Sports centers }(6)\end{array}$ \\
\hline
\end{tabular}

Chan et al. found that the kiosks were frequently used in shopping centers, docks, hospitals, walk-in centers, and "Kwik Save" supermarkets; they were least used in community centers, youth centers, and citizen consultation offices. This indicated the necessity of deploying kiosks in health centers and hospitals (14). Jones et al. concluded that the type of service, the content of kiosks, and the kiosk model should be taken into account when deciding where to deploy the kiosks. They also pointed out that people do not consider the results of public kiosks very seriously (1).

\section{Kiosk users}

Among studied articles, 13 articles listed user characteristics as well as human variables affecting kiosk usage:

Olufunmilola et al. showed that the women utilized USbased health kiosks four times more than men. Most kiosk users were 60-69 years old, blacks, college-educated, and middle-low income level (annual income: 25000-75,000 \$) (31). Hsieh et al. indicated that the average age of those using HIV test kiosks ranged from 39 to 40 years old, and the highest frequency was associated with the 25-54 age group. In this study, the women and African-American blacks were reported to be the most frequent users of kiosks (22). Agard et al. investigated the computerized management of asymptomatic urinary tract infections in health kiosks and found that most women who utilized kiosks were in the $25-44$ age range (15). Over $76 \%$ of mental problem examination kiosks' users in Canada were women; their age group was 30-50 years old, had postgraduate education degree, with middle-high income level (75000-150000 \$), and white Canadian and European (15). The users of APHID kiosks who were Portland soldiers and veterans were mostly men $(90.6 \%)$ with a mean age of 60.8 years old (11). Users of blood pressure control kiosks in Singapore were patients with chronic diseases, mostly 61-70 years old women, Chinese, with secondary education level, and with high triglyceride levels (10). The target group of kiosks at Lesselroth et al. study was 8 million military personnel and retired staff (33). Porter et al. showed that the parents of children with asthma could utilize kiosks; most of them had high school or college degree, were non-native blacks, more than $80 \%$ of them had used ATMs during the past one month, and had worked easily with it (35). The average time spent in working with public health kiosks in Iran is 4 minutes; $90 \%$ of users are above 40 years old and young people utilize it only to control their height and weight and for astrology (6). Older users with a college degree use more mental illness management kiosks (36). The war veterans' chemotherapy unit kiosks in Portland were frequently used by people with average age of 54-year-olds who were male, white or African-American, and with high school or university degree (24). In one study, the participants believed that people's attitudes toward technology in general and the safety of devices, meeting user needs, easiness of utilization, privacy, cost, and the appearance of kiosks in particular may influence people's willingness to utilize them (37). Also, Courtney et al. emphasized that specific problems in the health conditions of people and providing their needed services through kiosks are most important variables to utilize such a tool (38). On the other hand, Chan et al. believed that gender, age, education level, race, neighborhood, and waiting time of users in clinics had no significant effect on kiosk effectiveness (14).

\section{Design and construction requirements}

Some factors should be considered in designing the kiosks: ease of use, easy and quick understanding of kiosk objectives, not needing special skills to utilize it, compliance with needs of people with disabilities such as using audio files for blind and illiterate people, bilingualism, high-speed service and information delivery, updated based on current processes, users' data security, and privacy considerations such as monitor size, type font, and proper partitioning. Also, the important considerations for designing kiosk systems for the emergency department include hardware motion, modular approach for entering data, visual simplicity, and ease of physical and cognitive utilization. The designers should ensure that the data can also be entered without using a keyboard, a multimedia approach is present for collecting and disseminating patient-specific health information, the machine language is simple, the medical concepts are provided in intelligible language to patients, and the error correction and editing strategies are available to ensure maximum patient input accuracy (14). Adding any new device or feature should not disrupt the provision of the previous services (11). The attractive information content (26), identifying the physical, mental, and data security risks (28), detecting various errors including software errors, user interface errors, and the adding new features to the system (37), providing needed resources such as computer, monitor, Windows $\mathrm{XP}$, and various software, Internet connectivity, printers, 
headphones, and touch screens (27), attention to security, privacy, confidentiality, integrity, and appropriate levels of access to information (28), bilingualism and ability to utilize them through voice by special headsets (18), using different modules such as introduction, symptom report, medicine report, home care and evaluation needs, and output (35), applying balanced approaches to mitigate data security risks and information theft (1), and user involvement in designing and construction (39) were considered in designing the kiosks.

\section{Disadvantages and challenges of using kiosks}

The disadvantages and challenges of using kiosks have been classified into four categories as shown in Table 4 .

This study aimed to provide a comprehensive view of using health kiosks in the world in order to help managers and policymakers to decide on installing in their country's official health system.

\section{Provided service}

The findings showed that kiosks might provide various prevention, counseling, and educational services, demographic characteristics, and patient health history.

All new health technologies can provide a wide range of services - from consulting and information to precision invasive operations. While mobile health apps may pro- vide exercise, fitness, pedometer and heart rate monitoring, diet and weight management, blood pressure monitoring, diabetes and sleep disorders counseling (1, 40-43), some robotic surgical devices allow a surgeon to operate remote-controlled robotic arms (44), and health kiosks are in the middle of this spectrum.

\section{Benefits and effectiveness of kiosks}

Kiosks may promote health system indices such as accessibility and justice in the countries. The provision of diagnostic and medical services and medicine is the key difference between integrated kiosks and other health technologies (1) which can evolve the health system into telemedicine in the case of online connection to physicians. In this regard, Courtney et al. emphasized that health kiosks may increase the access of the elderly, the disabled, and those with low socioeconomic status to services (45). This technology may be successfully utilized in remote areas; for example, India successfully launched a national project in 2008 to provide sustainable health services to rural areas (41) and Germany connected the smart health cards to kiosks to integrate kiosk services in the health system (20).

Limited studies have confirmed the cost-effectiveness of health kiosks. However, Torre-diez et al. studied other technologies such as Mobile Health and achieved contra-

Table 4. The disadvantages and challenges of using kiosks

\begin{tabular}{|c|c|}
\hline $\begin{array}{l}\text { Categories of The disadvantages } \\
\text { and challenges }\end{array}$ & Examples (codes) \\
\hline Kiosk management challenges & $\begin{array}{l}\text { Lack of organizational leadership (25), disregarding human-technology relationships (18), lack of coor- } \\
\text { dination between kiosk staff and their support staff (11), lack of some database required in systems or } \\
\text { usage of unintegrated databases (11), fear of tampering of systems and information theft (1), difficulty in } \\
\text { selecting medicine by patients to be recorded in medical history (11), concerns on the inappropriate re- } \\
\text { sponse from users or service providers to kiosk results such as panic due to over-focus on results and } \\
\text { even replacement of regular medical controls with kiosk controls (38), low acceptance of kiosks (18), } \\
\text { and uncertainty about the access of all people in society to kiosks services. }\end{array}$ \\
\hline
\end{tabular}

Challenges of designing and deploying kiosks

User-related challenges

Staff- related challenges
Disregarding ethnographic investigation and paying attention to socio-cultural analysis in designing and constructing kiosks (18), disregarding people's values and culture and issues such as staff relationships, target population, and professional identities which may be effective in social acceptance of these kiosks (18), improper deployment location (38), disregarding patient privacy, infection transmission, and incompatibility of some equipment with physical features of users such as people who use wheelchair, are short heighted, have very long arms, or are too thin to use barometer cuff $(21,32)$, kiosks' appearance unattractiveness (38), insufficient visual motivation in kiosks to complete service delivery process, inappropriate environments which distract individuals in time of using kiosk, and interoperability of kiosk applications with clinic's current process (25), inappropriate deployment environments such as crowded and stressful environments (38), and lack of connection between health e-card and e-health kiosks (19)

Human knowledge and belief in self-intervention (21), people attitude toward this tool and believing that the physicians and health service providers may be replaced with kiosks $(10,18)$, insufficient evidence of device usefulness and acceptability by target groups (18), the resistance of some people such as the elderly people to utilize new technologies (21), concerns of users on some social-psychological issues such as communication and sharing information with healthcare providers, the logistical concerns including the physical safety of kiosks, worrying about privacy of users' response and results of kiosks, and worrying about device safety (38), distrust in data security (1), concerns over replacing the human resource with kiosks in the system (6), and self-selection bias limits in kiosks which diagnose and manage mental illness (36)

The resistance of staff due to misconception of increasing workload $(11,18)$, physicians' resistance due to possibility of losing the patients and lack of accountability in results presented in kiosks $(1,21)$, uncertainty in the accuracy of results of kiosks and presence of confusing results $(21,26)$, concerns about changing work responsibilities and occupational safety (21), resistance due to the time and effort needed by staff to deploy and maintain the application (25), concerns on poor communication between kiosk staff and patients, and ultimately, concerns on the quality of provided care (38) 
dictory results on their cost-effectiveness and benefit (42). Given the limited evidence in this area, this result is not generalizable.

\section{Deployment locations}

The integrated health kiosks have been used both in public and in specialized medical areas around the world. It seems that the objectives of makers and their defined functions are the most important influencing factors; the specialized and sometimes invasive health services such as HIV and HPV screening, HPV vaccination, management of UTI infections in women, and the like are provided in specialized areas, and the kiosks which provide services such as public health, elderly health, vital symptom control, and life quality indicators of elderly people are deployed in public places. The kiosks in crowded areas such as shopping malls, clinics, and hospitals allow the provision of health information to a wide audience, regardless of their age, race, language, education level, or gender and can provide significant financial benefits to investors and thus encourage them to participate in the provision of health services. On the other hand, deploying them in remote areas or at the time of disasters may promote the indicators of accessibility and justice in the health system. The same was true about opportunistic kiosks. In their study on pediatric opportunistic kiosks, Thompson et al. found that they are placed in low-income urban areas including public library, motor vehicle office, and restaurant (43). However, Chan et al. showed that opportunistic kiosks had been utilized in various countries both in specialized medical places and in public places (14).

\section{Kiosk users}

Kiosks can be utilized by various demographic groups based on their demographic and functional objectives. The selected studies showed that various demographic groups such as men and women at different age groups and races, soldiers, retired militaries, people with disabilities, youth and the elderly, the illiterate and the educated people, the sick and healthy individuals had utilized health kiosks. It seems that most people are not reluctant to utilize new technologies; if their benefits are proved, they will accept them. The technology adoption model also confirms that in addition to personality traits and disease conditions of individuals, the perceived usefulness and perceived ease of use encourage the use of technology (31). In another study, in addition to these two factors, four other factors were determined as affecting the people's decision to use effectively: perceived enjoyment, technology literacy, security and privacy, and Internet connection quality (46). The acceptance of using smart magnetic bracelets to communicate with nurses after hospital discharge in Southon et al. study (47) and using mobile health applications in Lee et al. study confirm this finding (48).

Therefore, it is necessary to consider the predictor variables of using kiosks with respect to provided services and target groups during the design and construction of kiosks. Obviously, these variables vary in different age groups, education levels, and even physical, mental, and emotion- al states. For example, Deng et al. showed that the perceived value, attitudes, perceived behavior control, and resistance to change were predictive variables of middleaged people to utilize mobile health; in the case of elderly people, in addition to above factors, the anxiety of using technology and the real need for services also impacted on their utilization of this technology (49).

\section{Design and construction requirements}

The factors which should be considered in design are the same in various health technologies. According to the findings of the present study, Ofcom (2009) reported that mobile popularity, their mobility, and their technological capabilities are the variables influencing mobile health utilization (50). Matthew-Maich et al. found that a usercentered, participatory, and interdisciplinary approach is needed to promote the feasibility, acceptability, and usability of health innovations such as mobile health (5). Also, paying particular attention to privacy in cases where social stigma will follow is as essential as managing highrisk behaviors (51).

The issues such as data security (52), ease of using the equipment of kiosks (53-56), the interaction between private and public information of people via Bluetooth connectivity (57), being multipurpose, personalization of content delivery, customer-friendliness, and flexibility (45), compatibility with human ergonomics, even in people with special conditions (58), and audio file playback if necessary (35) have all been emphasized in various studies and in various health technology tools.

\section{Disadvantages and challenges of using kiosks}

Despite the benefits of using kiosks, there are challenges and concerns on the development of this technology. The security of data at the device, quality of information and services, calculation of service prices, advertising protocols, privacy, and most importantly not conveying emotion, hope, and comfort to patients and users are some factors that need to be considered and appropriate solutions should be provided for them (13). The studies emphasized that if managers' attention and support decline over time, the acceptance and ultimately the effectiveness of this tool will weaken. For example, Indian National Project (2008) provided 100 kiosks to rural areas (Sari) for their sustainable access; but, about 30 percent were disabled over time due to infrastructure problems such as the Internet and lack of financial support (41).

Due to cost-effectiveness constraints, on the other hand, the decision to deploy kiosks requires careful economic evaluation in all countries. Obviously, the opinions of all stakeholders, such as insurance agencies, medical equipment importers, electricity companies, telecommunications, and people need to be taken into consideration. For example, if the tariff is not consistent with the income of people, it can completely reverse the process of equality in health and lower the benefits of these services to lucrative services level.

\section{Conclusion}

Using health kiosk is a promising, cost-effective, and 
versatile way to enhance universal health coverage in all three dimensions: population coverage, financial protection, and delivering services.

They can provide prevention, counseling, and educational services, demographic characteristics, and patient health history, which their effectiveness and benefits have been proven in various studies. The target group and the types of services are the most important variables affecting their location. These variables need to be determined based on the epidemiology of national disease and health indicates in the country.

The representatives of all stakeholders, especially the target group, should involve in the design and construction phase and the feasibility, acceptability, usability, security, personalization and flexibility of equipment, should be addressed.

It can be installed in the formal health system; however, its challenges should be addressed before.

\section{Limitations}

Most studies have been conducted in the US or European high-income countries; therefore, the generalizability of the findings to other countries is limited. Also, the diversity of integrated kiosks and their heterogeneity makes it difficult to summarize the findings. There is also limited evidence on the financial role of kiosks in health.

\section{Future research}

This topic can be studied exclusively in developing countries. Also, the variables affecting the use of health kiosks, especially cultural variables, the cost-effectiveness of using kiosks, comparative study of the role of kiosks and other new health technologies nowadays, the efficiency and effectiveness of kiosks and finally their evaluation methods, can be considered at future research.

\section{Funding}

This study was a part of a Ph.D. thesis entitled "Developing a health service delivery model through health kiosks in Iran" and funded by the School of Health Management and Information Sciences, Iran University of Medical Sciences, Tehran, Iran. (Research code: IUMS/SHMIS 97-3-37-13007 and research permission code from Ethics Committee: ir.iums.rec.1397.480).

\section{Acknowledgment}

We would like to acknowledge the Iran University of Medical Sciences for the financial support.

\section{Conflict of Interests}

The authors declare that they have no competing interests.

\section{References}

1. Jones R. The role of health kiosks in 2009: literature and informant review. Int J Environ Res Public Health. 2009;6(6):1818-55.

2. Williams $P$, Nicholas D, Huntington P. Non use of health information kiosks examined in an information needs context. Health Info Libr J. 2003;20(2):95-103.

3. Nicholas D, Williams P, Huntington P, editors. Health information kiosk use in health organisations: the views of the health professionals. InAslib Proceedings: new information perspectives; 2001 Nov 1. Emerald Group Publishing Limited. 2001;53(9):368386.

4. Strecher VJ, Greenwood T, Wang C, Dumont D. Interactive multimedia and risk communication. JNCI Monographs. 1999;1999(25):134-9.

5. Matthew-Maich N, Harris L, Ploeg J, Markle-Reid M, Valaitis R, Ibrahim S, et al. Designing, implementing, and evaluating mobile health technologies for managing chronic conditions in older adults: a scoping review. JMIR Mhealth Uhealth. 2016;4(2):e29.

6. Shahmoradi L, Hosseini RM, Aslani N, Shahidzade M. The role of health kiosks in public health. Health Inf Manag J. 2015;3(43):37989.

7. Hsieh CT. Implementing self-service technology to gain competitive advantages. Commun IIMA. 2005;5(1):9.

8. Lowe C, Cummin D. The use of kiosk technology in general practice. J Telemed Telecare. 2010;16(4):201-3.

9. Lesselroth BJ, Adams K, Tallett S, Ragland S, Church V, Borycki EM, et al. Usability evaluation of a medication reconciliation and allergy review (MRAR) Kiosk: a methodological approach for analyzing user interactions. Stud Health Technol Inform. 2015;61-7.

10. Ng G, Tan N, Bahadin J, Shum E, Tan SW. Development of an automated healthcare kiosk for the management of chronic disease patients in the primary care setting. J Med Syst. 2016;40(7):169.

11.Lesselroth BJ, Felder RS, Adams SM, Cauthers PD, Dorr DA, Wong GJ, et al. Design and implementation of a medication reconciliation kiosk: the Automated Patient History Intake Device (APHID). J Am Med Inform Assoc. 2009;16(3):300-4.

12. Houle SK, Chuck AW, Tsuyuki RT. Blood pressure kiosks for medication therapy management programs: business opportunity for pharmacists. J Am Pharm Assoc. 2012;52(2):188-94.

13. Bynum W. Why physicians need to be more than automated medical kiosks. Acad Med. 2014;2(1):212-4.

14.Chan YFY, Nagurka R, Bentley S, Ordonez E, Sproule W. Medical utilization of kiosks in the delivery of patient education: a systematic review. Health Promot Perspect. 2014;4(1):1.

15.Agaard EM, Nadler P, Adler J, Maselli J, Gonzales R. An interactive computer kiosk module for the treatment of recurrent uncomplicated cystitis in women. J Gen Intern Med. 2006;21(11):1156-9.

16.Krishna S, Boren SA, Balas EA. Healthcare via cell phones: a systematic review. Telemed J E Health. 2009;15(3):231-40.

17. Moher D, Liberati A, Tetzlaff J, Altman DG, Altman D, Antes G, et al. Preferred reporting items for systematic reviews and metaanalyses: the PRISMA statement (Chinese edition). Chin J Integr Med. 2009;7(9):889-96.

18. Ackerman SL, Tebb K, Stein JC, Frazee BW, Hendey GW, Schmidt LA, et al. Benefit or burden? A sociotechnical analysis of diagnostic computer kiosks in four California hospital emergency departments. Soc Sci Med. 2012;75(12):2378-85.

19. Venkatesh V, Rai A, Sykes TA, Aljafari R. Combating infant mortality in rural India: Evidence from a field study of ehealth Kiosk Implementations. Mis Quart J. 2016;40(2):353-80.

20.Zwicker M, Seitz J, Wickramasinghe N. Adaptations for e-Kiosk systems in Germany to develop barrier-free terminals for handicapped persons. Critical issues for the development of sustainable e-health solutions: Springer; 2012; 99-112.

21. Chung C-F, Munson SA, Thompson MJ, Baldwin L-M, Kaplan J, Cline R, et al. Implementation of a new kiosk technology for blood pressure management in a family medicine clinic: from the WWAMI Region Practice and Research Network. J Am Board Fam Med. 2016;29(5):620-9.

22.Hsieh Y-H, Holtgrave DR, Peterson S, Gaydos CA, Rothman RE. Novel emergency department registration kiosk for HIV screening is cost-effective. J Assoc Nurses AIDS Care. 2016;28(4):483-6.

23. Wrenn G, Syed I, Kasiah F. Using a self-service kiosk to identify behavioural health needs in a primary care clinic serving an urban, underserved population. BMJ Health CareInform. 2015;22(3):323-8.

24.Lesselroth B, Adams S, Felder R, Dorr DA, Cauthers P, Church V, et al. Using consumer-based kiosk technology to improve and standardize medication reconciliation in a specialty care setting. Jt Comm J Qual Saf. 2009;35(5):264-AP1.

25.Jones J, Arant R, Treichler B, Idris A, Suter R. 205: Implementation of a self-service kiosk system in the ED: Are more patients leaving than we think? Ann Emerg Med. 2008;51(4):533.

26.Hopfer S, Hecht M, Ray A, Miller-Day M, BeLue R, Zimet G, 
editors. Feasibility of implementing a community clinic based interactive health kiosk about HPV vaccination targeting African American young adult women attending Planned Parenthood. Implement Sci. 2017;12(236).

27. Afzali M, Ahmadi M, Mahmoudvand Z. Data requirements and the basis for designing health information kiosks. Acta Inform Med. 2017;25(3):198

28. Takyi H, Watzlaf V, Matthews JT, Zhou L, DeAlmeida D. Privacy and security in multi-user health kiosks. Int $\mathrm{J}$ Telerehabil. 2017;9(1):3.

29. CONNELL CM, Shaw BA, Holmes SB, Hudson ML, Derry HA, Strecher VJ. The development of an Alzheimer's disease channel for the Michigan Interactive Health Kiosk Project. J Health Commun. $2003 ; 8(1): 11-22$.

30.Ahn HS, Kuo I-H, Datta C, Stafford R, Kerse N, Peri K, et al., editors. Design of a kiosk type healthcare robot system for older people in private and public places. International conference on simulation, modeling, and programming for autonomous robots; 2014: Springer.

31. Abraham O, Patel M, Feathers A. Acceptability of health kiosks within african american community settings: A pilot study. Health Serv Res Manag Epidemiol. 2018;5:2333392817752211.

32. Green B, Chia-Fang C, Baldwin L-M, Thompson MJ, Munson SA. Flip the clinic: implementing patient self-measurement of blood pressure using a kiosk in a clinic waiting room. J Am Soc Hypertens. 2016;10(4): 25-9.

33.Lesselroth BJ, Holahan PJ, Adams K, Sullivan ZZ, Church VL, Woods S, et al. Primary care provider perceptions and use of a novel medication reconciliation technology. Inform Prim Care. 2011;19(2):105-18.

34.Hsieh Y-H, Gauvey-Kern M, Peterson S, Woodfield A, Deruggiero $\mathrm{K}$, Gaydos CA, et al. An emergency department registration kiosk can increase HIV screening in high risk patients. J Telemed Telecare. 2014;20(8):454-9.

35.Porter SC, Cai Z, Gribbons W, Goldmann DA, Kohane IS. The asthma kiosk: a patient-centered technology for collaborative decision support in the emergency department. J Am Med Inform Assoc. 2004;11(6):458-67.

36. Maunder R, Hunter J. The Self-Assessment Kiosk: Development and implementation of an internet resource for self-assessment of mental health and health behavior that provides personalized feedback. J Psychosom Res. 2018;109(3):118-9.

37. Courtney KL, Matthews JT, McMillan JM, Mecca LP, Smailagic A, Siewiorek DP, et al. Usability testing of a prototype multi-user telehealth kiosk. Itch (Phila). 2015;488(6):109-14

38. Courtney KL, Lingler JH, Mecca LP, Garlock LA, Schulz R, Dick AW, et al. Older adults' and case managers' initial impressions of community-based telehealth kiosks. J Gerontol Nurs. 2010;3(4):2359 .

39. Mandato K. Successful implementation of patient self-check-in kiosks from a frontline service employee perspective: A qualitative study of best practices: Capella University; 2010. (Ph.D Tesis).

40.Fox S, Duggan M. Mobile health 2010: Pew Internet and American Life Project Washington, DC; 2010. available in http://marketingfarmaceutico.com/wp-content/uploads/2012/11/PEW_MobileHealth 2012.pdf

41.Best ML, Rajendra K. Sustainability failures of rural telecenters: Challenges from the sustainable access in rural india (sari) project. Inf Technol Int Dev. 2008;4(4):31-45

42.De La Torre-Díez I, López-Coronado M, Vaca C, Aguado JS, de Castro C. Cost-utility and cost-effectiveness studies of telemedicine, electronic, and mobile health systems in the literature: a systematic review. Telemed J E Health. 2015;21(2):81-5.

43. Thompson DA, Lozano P, Christakis DA. Parent use of touchscreen computer kiosks for child health promotion in community settings. Pediatrics. 2007;119(3):427-34.

44.Barbash GI. New technology and health care costs--the case of robot-assisted surgery. N Engl J Med. 2010;363(8):701.

45. Courtney K. Designing the community multiuser health kiosk. Enabling Health and Healthcare Through ICT: Available, Tailored and Closer. 2013;183:79.

46.Pikkarainen T PK, Karjaluoto H, Pahnila S. Consumer acceptance of online banking: an extension of the technology acceptance model. Internet Res. 2004;14(3):224-35

47. Southon FCG, Sauer C, Dampney CNG. Information technology in complex health services: organizational impediments to successful technology transfer and diffusion. J Am Med Inform Assoc. 1997;4(2):112-24.

48. Lee J, Rho MJ. Perception of influencing factors on acceptance of mobile health monitoring service: a comparison between users and non-users. J Healthe Inform Res. 2013;19(3):167-76.

49. Deng Z, Mo X, Liu S. Comparison of the middle-aged and older users' adoption of mobile health services in China. Int $\mathrm{J}$ Med Inform. 2014;83(3):210-24.

50. Ofcom. The consumer experience: telecoms, internet and digital broadcasting. 2009. available in https://www.ofcom.org.uk/.

51.Krishnan A, Ferro EG, Weikum D, Vagenas P, Lama JR, Sanchez J, et al. Communication technology use and mHealth acceptance among HIV-infected men who have sex with men in Peru: implications for HIV prevention and treatment. AIDS Care. 2015;27(3):273-82.

52.McIntosh S, Pérez-Ramos J, Demment MM, Vega CV, Avendaño E, Ossip DJ, et al. Development and implementation of culturally tailored offline mobile health surveys. Public Health Surveill. 2016;2(1):e28.

53. Bluth C, Bluth J, Bryan RG, Lovell JC. Health care kiosk with handicapped accessible seat. United states Patent; US 6,428,124. 2002.

54. Bluth CP. Triage based managed health kiosk system. United States patent application US 12/407,682. 2009.

55.Collins J, Kavars CL, Davis LG, Green RL. Health assessment kiosk. United States patent application US 29/176,834. 2005.

56. Bluth C, Bluth J, Bryan RG, Lovell JC, Hicksted RL, Spahr MA. Seat scale for health care measurement kiosk. United States patent US 6,403,897. 2002.

57.Huang A, Pulli K, Rudolph L, editors. Kimono: kiosk-mobile phone knowledge sharing system. Proceedings of the 4th international conference on Mobile and ubiquitous multimedia; 2005:142-9.

58.Lyu Y, Vincent CJ, Chen Y, Shi Y, Tang Y, Wang W, et al. Designing and optimizing a healthcare kiosk for the community. Appl Ergon. 2015;47:157-69. 
Appendix

( ( ( ALL ( patient) OR TITLE-ABS-KEY ( clinical) OR TITLE-ABS-KEY ( health) OR TITLE-ABS-KEY ( medical) OR TITLE-ABSKEY (hospital) OR TITLE-ABS-KEY (treat*) OR TITLE-ABS-KEY (screen*) OR TITLE-ABS-KEY ( check AND in ) OR TITLEABS-KEY ( check-in ) OR TITLE-ABS-KEY (care) OR TITLE-ABS-KEY ( diagnos*) OR TITLE-ABS-KEY ( test)) ) AND (TITLE (kiosk*)) AND (( TITLE (design*) OR TITLE (implement*) OR TITLE (model*) OR TITLE (pattern*) OR TITLE (framework) )) ) AND NOT (( TITLE (informat*) OR TITLE (learn*) OR TITLE ( educat*))) AND (LIMITTO ( LANGUAGE, "English" ) ) 